\title{
Sustainability Symbol of Justice
}

\author{
Noor Farihah Mohd Noor \\ College of Government, International Studies and Law, University Utara Malaysia
}

\begin{abstract}
Quality of life has very much to do with being sustainable. In a country where development and money is the means of progressing making profits, are unavoidable. But does the quest for progress hamper sustainability? Sustainability is important because it reflects a balance between freedom and power, independence and authority, rich and poor, justices and oppression. We have seen much oppression that emerges from exercising public power. Despite the formation of institution like integrity bodies, separate organizations to combat corruptions, tribunals and the like, yet public oppression never subside. Rudeness, unwillingness to treat the complainant as a person with rights; refusal to answer reasonable question; neglecting to inform complainant on request of her entitlement; knowingly giving misleading or inadequate advice; ignoring valid advice or overruling consideration which would produce an uncomfortable result for the overuler; offering no redress or manifestly disproportionate redress; showing bias on colour or whatever ground; refusing to inform adequately the right of appeal ; failure to mitigate the effect of rigid adherence to which it can produce manifestly inadequate treatment are all forms of malfeasance of the modern days. The focus of this paper thus is to look at the possible ways of combatting bad administration via judicial review of administrative action. What's interesting is the ability of the court to tease out the complicated issues so that justice could be delivered. Justice is far-reaching if it can be exercised beyond merely the judicial scrutiny. Being able to address the lack of justice is in fact a reflection of sustainability and high quality of life.
\end{abstract}

Keywords: Justice; sustainability, abuse of power, judicial review

\section{Introduction}

\section{What constitute justice?}

Justice can be achieved by many means. One way is manifested by way of putting things in a rightful place as well preventing all kinds of oppression. Since justice cannot exist without a transparent legal system, the main components of which must embrace clear set of laws that are freely and easily accessible to all, strong enforcement structures, and an independent judiciary to protect citizens against the arbitrary use of power by the state, individuals or any other organization. That being said accountability is no exception. It is also associated with justice. R Mulgan for instance saw accountability in protecting the public's rights. He asserted accountability provide opportunities for otherwise weak and defenseless subjects to impose some control on powerful organizations and individuals who are supposed to be serving their interest (R Mulgan, 2005). Gaudron J in the case of Corporation of the City of Enfield v Dev Assessment Commission (2000) 199 CLR 135 saw limiting the government power as part of accountability. He asserted accountability can be taken to refer to the need for executive government and administrative bodies to comply with the law and in particular, to observe relevant limitations of their power. For Dawn Oliver, accountability is about requiring to explain and justify against criteria of some kind, their decisions or acts and then to make amends for any fault or error whether by reversing the decision or paying compensation or in some other way- even resigning from office (Dawn Oliver, 2003). Thus the lists are by no means exhaustive.

In another word how the courts interpret the laws to translate justice give rise to the above said results (Shad Saleem Faruqi, 2008). This can be seen among others from how the court defines the law on power to regulate and prohibit as exhibited in the Australian case. 


\section{Power to Regulate and Prohibit}

Cases have shown how the authorities should exercise the power to regulate and prohibit. It is through these powers that court can identify whether the authorities have exceeded their power in prohibiting and in regulating the rules. Order of prohibition cannot be exercised freely without control. Such act may amount to abuse of discretionary power. This is implied in the case of Swan Hill Shire v Bradbury (1937) HCA 15; 56 CLR 746. Under the Local Government Act 1915 Swan Hill Council, sec 198 (1) stipulated that the council can make by-laws to regulate and restrain the construction of buildings, fences on or within ten feet of any street road. So the Swan Hill Council made by-laws in clause 4 conferring power to restrict the building of shops, houses etc unless with approval of the council. The following provisions also confer powers to consider the situation of the building like the plan, materials and estimated cost and 'any such particulars (necessary' to enable the council or its surveyor to determine whether all the provisions in the by-law are complied with. The Supreme Court of Victoria held that clause 4 of the by laws as invalid. The Council appeal. On appeal the Full Court affirmed the decision of the earlier court and dismissed the appeal.

Dixon $\mathrm{J}$ justified that there is no express limitation on the discretion upon the council to approve or disapprove proposal to build. If understood properly the clause intended to give wide discretionary power to the council to the extent that the council can restrict and determined in advance whether the building is fit to be constructed. There is nothing to show that the restriction to build shop buildings was not intentional. Abuse easily occurs where power is wide and undefined. This was worsens when compliance with the by law include not only intention to build but extend further to estimating the cost of building, planning etc. This type of by-law is silent on whether due reason is needed for the council to withhold approval to build. The object of framing such a clause was not to make it an exceptional privilege lying in the special grace of the council. There are reasons why discretionary power is given to the council, maybe legislature distrusts itself to formulate in advance standards that would prove sufficient in all infinite circumstances. Thus when a provision of this kind is made, it is incumbent on public authorities to exercise the discretion with bona fide consideration and without intention to achieve other ends and purpose other than what it is supposed to uphold. The duty may be enforced by mandamus.

Court has to be careful with discretion that was almost without definition. If it were valid, the aggrieved person would be entitled to insist that his application would deserve the council consideration and if it was refused and he was able to prove such refusal was not bona fide or was prompted by motives which fell out of the scope and purpose of the by-law, he would still be entitled to claim its reconsideration. But if the council plainly restricts them, the right of the aggrieved will end there.

Dixon $\mathrm{J}$ beautifully stated that unless and until the opportunity is open to the aggrieved to challenge the council, he would never be able to compel the council to decide reasonably in his favor. And until such approval is given, the aggrieved would be committing an offence against the by-law should he continue to construct the building. Moreover, to show the reason for refusing his application would be no easy thing. Every explanations relating to the development of community locale amount to reasons. Dixon J justified, no reason would be held outside the scope and purpose of by laws except it has no link with municipal government. In other word all public reasons are amendable to review unless it has no relevance to authorities concern. Furthermore, although the construction of the building is regarded as a form of activity which maybe unregulated and as a result, expose to abuse and exploitations but that itself is not a thing to be repressed.

Dixon's forceful criticism in terms of regulating and prohibiting public activities is amazing. The power to regulate and prohibit may become evil in itself because if it is interpreted widely, it can authorize complete suppression or conditional prohibition within the power while the same expression can produce startling result if understood in different sense or in bona fide sense. The court concluded that clause 4 was invalid and the appeal should be dismissed.

The power to regulate and prohibit can also be looked at, from the proportionality perspective. The principle formulated by Jeffrey Jowell and Lester require the administrator, to maintain a proper balance between any adverse effect which its decision (may have on the rights, liberties or interest of persons and the purpose which it pursues (Jeffrey Jowell. 1995).

The concept of reasonable proportionality can be a test of validity to see whether the authorities' conducts are ultra vires or not. Davies v Commonwealth (1988) 166 CLR 79 thus laid out the guideline for proportionality test. First even if the purpose of law is to achieve an end within the scope of what is incidental to the main power it will not fall within the scope unless it is capable of being considered proportionately with the end of power? (And secondly, to see whether the law satisfied the reasonable proportionality requirement, it is important to determine the scope of law, does it go beyond what 
is necessarily desirable for the achievement of legitimate object meant to be attained? (By so doing the adverse consequences related to the goal can be avoided.

\section{Courts approach to justice in UK}

In UK discharging the constitutional ideals of justice is made by refining the policy choices. The UK has outlined the criteria of accountability in making policy choices. The standard requires for policy choices to be just and fair, there must be rationalization and prioritization of matters. Accountability lies largely in how choices are made. How can decision makers be made accountable for the wrong policy choices they made especially when it severely affect the public? (The people have a share in deciding the best policies that should govern them. This freedom is not without basis. This freedom in fact is rooted in the constitution. The essence of constitution lies in the assurance that these fundamental freedoms should be allowed to develop actively as long as it is not insulting and offensive to others. But government always curtails this freedom when they make policy choices. Policy choices are made without regard to public cry. Policy choices are made without ordering priority accordingly and often sidestepped those seriously affected by it (Diane Longley, 1999). Government often perceives public participation a nuisance and constantly ignores public protest. Because of this, courts through constitutional principle of fundamental liberties had to protect the people's freedom via its careful scrutiny.

Assessing values are hard because adopting policy choices depends on considerable connotations and interpretations. Such being the case, values are often left unarticulated. Priorities are put at the wrong place. Wrong solutions are made and compromises, always marginalized fundamental principle like fairness. Law $\mathrm{J}$ asserts court must understand this otherwise it is incapable of guiding the government against arbitrary policy making.

"Discretionary power is not about simple irrationality and failure to consider relevant matter but it is more concerned with how decision maker ordered his priority" (Law J, 1999).

Thus ordering matters based on priority will give rise to accountability. Prioritizing policies to benefit and support the public is what makes it just. Governmental choices therefore must be properly guided as essence of discretionary power actually lies in the ability to choose which among the important matters are most instrumental and to order them accordingly so that justice can be delivered (Diane Longley, 1999).

This substantive fairness is in line with the concept of constitutionalism. Even though the court must not to go beyond the procedural rule but one must bear in mind that such exclusion is subject to upholding the just values which constitutionalism summon. Constitutionalism is nothing but restraints of government arbitrary power. As Thomas Paine forcefully asserted, "government without a constitution is power without rights" (Thomas Paine, 2008). Eric Brandt too asserted that government that truly upholds the constitution is a democratic government and vice versa. ' The court too stressed that as long as these are observed, it will not be hostile to the authorities (Eric Brandt, 1998).

Acting according to the law does not mean blind submission to the unjust law but the opposite. In other words, "government according to law" means that it is repugnant for government to abuse its power. This strong call for justice also meant that, court could review not only procedural but substantive power of the government (Mark Elliot, 2001).

$\mathrm{RH}$ Hickling expanded it further, for man-made law to claim recognition, it must be in harmony with God's law otherwise it will indeed be unjust and arbitrary;

The notion of law emerges at first sometimes so closely identified with the supernatural that it become so formidable as to become rigid like the ten commandment brought down by Moses and the old constitution of Johor, it could no way be changed, it was clothed with divinity, it represented the word of God and no human authority was competent to alter or revoke it. Philosopher began to consider the nature of truth and justice and to claim that the law of man must strive to be just and in harmony with the law of God (RH Hickling, 2001).

\section{Sources of Justice.}

Speaking of justice, the sources thus need to be highlighted. Indeed, courts' basic powers are mostly found in the constitution that derives its sources from the divine law. These powers are implied and inherent and because of the rich constitutional foundation, no expressed exclusion of courts power can discard and eliminate this inborn status. RH Hickling concurred with this notion and strongly claimed that fundamental of the divine law must accompany man made law in order for it to be just. If the divine law is sacred so are the constitutional principles because constitution possesses the energy 
derivable from divine root not accessible by ordinary human being. The revelations of the holy testament to Prophet Musa a. s and Prophet Muhamad s. a. w are not the making of human principles but of God the All Mighty. As RH Hickling said no human power are competent to override these as they are the words of God. Thus human made law must be in harmony with the divine law to be acceptable. In fact, RH Hickling said it is from this root that other branches of justice started to grow and develop continuously to suit the changing time and circumstances.

He compellingly justified;

When powers are assumed by the ruler it still has a natural content that is sacred, then by instinct men realized that it must be tempered with wisdom. All Malay rulers understood this. Wisdom seeks righteousness and righteousness seeks stable values and principles to aspire justice (RH Hickling, 2001).

He further reinforced the necessity of law arise not only from the divine law but must corroborate with it;

A well behave society can reject letters of thousand of laws but for the rest of us, some rules for the avoidance of physical and emotional collision are necessary. It is in the evolution of these rules that the history and rationale of our legal system can be found; and they themselves have grown out of the truths of religion (RH Hickling, 2001).

He further reinforces that law must uphold justice and moral standards as in such absence corruption and exploitations are bound to happen. He quotes what Devlin said that:

If law is out of touch with the moral consensus of the community whether by being either too far below it or too far above it, the law is brought into contempt. Virtue cannot be legislated into existence but non-virtue can be if the legislation renders excessively difficult the struggle after virtue. Such situation can have an eroding effect on the moral ethos of the community in question. The ultimate justification of law is that it serves moral ends (RH Hickling, 2001).

\section{Courts approach to justice in Malaysia}

In Malaysia likewise other countries, portray justice more in a legal context rather than outside it. This can be seen in the cases of constitutional supremacy which denies the omnipotence of parliament and the state of assemblies as well as submitting to the principles of fundamental liberties. These fundamental liberties include right to livelihood, freedom of assembly, freedom against retrospective punishment and right to property.

In Nordin Salleh v DUN Kelantan (1993) 3 MLJ 344. An amendment to Kelantan constitution requiring an assemblyman who 'crosses the floor' to vacate the seat and seek re-election was held to violate the fundamental right of association under art 10 as assemblyman are free to cross the floor as set under art 10 of Malaysian Federal Constitution.

Whilst in Govt of Sel vs Sagong Tasi (2005) Sagong Tasi \& 6 Ors vs Kerajaan Negeri Selangor \& 3 Ors (2002, 2 AMR 2028). The Aborigines Act 1954 must be brought into conformity with right to property in art 13 (2) of the constitution requiring compensation when acquiring customary land.

The court held that the plaintiffs were entitled to be adequately compensated for their customary land, compulsorily taken by the defendants to build the highway linking the federal capital with the KL International Airport (KLIA).

The brief facts, seven plaintiffs, Sagong and the six others, are members of the Temuan tribe. The first defendant, the Selangor State Government, evicted them and their families from their land in Kampung Bukit Tampoi in Dengkil, Selangor.

The judge concluded that the plaintiffs' rights under common law and the 1954 Act are proprietary rights protected under Article 13 of the Federal Constitution, and that compensation paid to them under the 1954 Act was not adequate within the meaning of Article 13 (2).

Justice also demands in punishing offences it must not be enforced retrospectively. All laws should be prospective, open and clear. As in the case of PP $\vee$ Mohamed Ismail [1984] 2 MLJ 219, where the defendant was charged with drug trafficking which was punishable with life imprisonment or death under sec 39B (1) of the Dangerous Drugs Act 1983. While his trial was pending, the law was amended to provide for a mandatory death penalty. At the close of the trial, the public prosecutor invited the court to impose the enhanced penalty. In refusing the request, the judge held that the amendment could not apply to the defendant's case as it was enacted after the offence was committed. 
Whilst in Lee Gee Lam v. Timbalan Menteri Hal Ehwal Dalam Negeri, Malaysia \& Anor [1993] 3 MLJ 265, the order of detention stated a number of grounds on which the detainee was apprehended, with the word 'or' and not 'and' in between. The court held that the statement of grounds in the alternative denied the detainee his constitutional right to know precisely the reason why he was being arrested thus unjust.

Whilst definition of "Life" in Tan Tek Seng v Suruhanjaya Perkhidmatan Pendidikan [1998] 3 MLJ 289 was define widely so as to give justice to the aggrieved. Tan Tek Seng (was charged with CBT and found guilty by High Court. Johor Education Department wrote to Education Service Commission (ESC), recommending Tan to be reduced in rank and salary. However, ESC decided to dismiss Tan and Tan appealed. It was held by the court that the Word 'Life' in Art 5 (1) not only refer to mere existence of someone but extends to all integral part of life itself and matters which form the quality of life including right to livelihood.

In Coelho v The Public Services Commission [1964] MLJ 12 wrongful dismissal was found by the court as unjust. In this case, the Respondent tried to terminate the Coelho based on the reason that the Coelho was appointed on probation. Then Coelho applied for certiorari to quash the dismissal. The Respondent advertised in the Malay Mail inviting applications for the post of an assistant Passport Officer. The applicant made an application and was subsequently accepted for a permanent post and letter of appointment was given on an unconditional basis. The appointment of the applicant was considered as an acceptance. Thus, there was a valid contract of employment. The termination of the applicant on probation thus was illegal as it was supposed to be unconditional offer.

All the above cases, reflects that to uphold justice the right and proper standards must be followed, absence of which can nullify the law and public actions.

\section{Conclusion}

The framework of justice has been depicted. The better it is implemented the stronger the quality of life of the people. This paper is pertinent as it has underlined how justice can prevent abuse of power that ultimately improves the quality of life of all walks of people. The upshot is that rigorous application of justice principles generates higher and better quality of life. Many tools and guidelines are constructed to combat bad governance as illustrated above. The cases in Australia and UK have shown that apart from procedural justice, substantive justice is also equally important. It lies in the domain of morality. The role of divine law in disciplining the positive law should be noted too. As power corrupts; absolute power corrupts absolutely. Due to that the courts were not hesitant to strike out laws which are oppressive and manipulative. The effectiveness of these tools though depends on how serious the concern authorities work to transform them. Sustainability thus can only materialize, in the context of justice manifested in the whole spectrum of life, legal and beyond.

\section{References}

[1] Coelho v The Public Services Commission [1964] MLJ 12.

[2] Corporation of the City of Enfield v Development Assessment Commission (2000) 199 CLR 135

[3] Davies v Commonwealth (1988) 166 CLR 79

[4] Dawn Oliver (2003), Constitutional Reform in the UK, Oxford: Oxford University Press.

[5] Diane Longley \& Rhoda James, (1999). Administrative Justice: Central Issues in UK and European Administrative Law. Cavendish Publishing, 1999)

[6] Eric Barendt, (1998). Constitutional Law (Oxford University Press, 1998), 4

[7] Govt of Sel vs Sagong Tasi (2005) Sagong Tasi \& 6 Ors vs Kerajaan Negeri Selangor \& 3 Ors (2002, 2 AMR 2028)

[8] Jeffrey Jowell in "An Introduction to Administrative Law" edited by Wan Azlan Ahmad, Mohsin Hingun (Pearson Professional (Singapore) Pte Ltd, 1995), 22

[9] Law J in Administrative Justice: Central Issues in UK and European Administrative Law by Diane Longley \& Rhoda James, (Cavendish Publishing, 1999), 26 
[10] Lee Gee Lam v Timbalan Menteri Hal Ehwal Dalam Negeri, Malaysia \& Anor [1993] 3 MLJ 265

[11] Mark Elliot, (2001). The Constitutional Foundations of Judicial Review. Hart Publishing, 2001), 191

[12] Nordin Salleh v DUN Kelantan (1993) 3 MLJ 344

[13] PP v Mohamed Ismail [1984] 2 MLJ 219

[14] R Mulgan in Robin Creyke and John McMillan, Government Action: text and Commentary (LexisNexis Butterworths, 2005), 7

[15] R. H. Hickling, (2001). Malaysian Law: An Introduction to the Concept of Law in Malaysia. Pelanduk, 2001), 2, 15

[16] Shad Saleem Faruqi. 2008). Document of Destiny - An Introduction to the Constitution of Malaysia. Star Publications (2008).

[17] Swan Hill Shire v Bradbury (1937) HCA 15; 56 CLR 746.

[18] Tan Tek Seng v. Suruhanjaya Perkhidmatan Pendidik \& Anor [1998] 3 MLJ 289.

[19] Thomas Paine, "Rights of Man in the Complete Works of Thomas Paine" in Constitutional and Administrative Law (ed. ) Micheal Allen \& Brian Thompson (Oxford University Press, 2008) 